\title{
Cross-border commuting and migration intentions: the roles of risk aversion and time preference
}

\author{
Klaus Nowotny ${ }^{1,2}$
}

\begin{abstract}
This article analyses the effects of individual risk aversion and time preference on cross-border mobility intentions using a theoretical and empirical model. The paper extends the previous literature by considering both cross-border commuting and migration as modes of mobility. The theoretical model shows that risk aversion has a negative effect on the willingness to migrate and to commute while the effect of time preference depends on expectations about the development of future wages in the home country and abroad. The empirical model, which is based on a multinomial probit regression, confirms the hypotheses regarding risk aversion and shows that the rate of time preference has a nonlinear effect on migration and commuting intentions consistent with expectations of higher real wage growth in the home country than abroad. The analysis sheds light on how time preference and risk aversion influence mobility decisions. This is especially important for integrating border regions in the European Union, in which both migration and commuting are possible.
\end{abstract}

KEY WORDS: $\quad$ willingness to migrate; willingness to commute; risk aversion; time preference; discount rate; migration and commuting intentions

JEL Classification: $\quad$ F22; R23; D80; D91; J61

${ }^{1}$ University of Salzburg, Austria; ${ }^{2}$ Austrian Institute of Economic Research WIFO, Austria

\section{Introduction}

The decision to become internationally mobile is always a decision under uncertainty surrounding the future states of important factors such as wage levels in the home country and abroad. However, while a variety of studies have analysed the effect of uncertainty on migration behaviour-such as the literature following Burda's $(1993$; 1995) works on the "option value of waiting", which links the investment literature of Pindyck and Dixit (see Dixit, 1992; Dixit and Pindyck, 1994;

Correspondence concerning this article should be addressed to: Klaus Nowotny, University of Salzburg Residenzplatz 9, A-5010 Salzburg, Austria. E-mail: klaus.nowotny@sbg.ac.at
Pindyck, 1991) to migration decisions (see O'Connell, 1997; Locher, 2001; Wang and Wirjanto, 2004; Anam, Chiang, \& Hua, 2008, to name just a few), or papers on the effects of individual risk attitudes on migration decisions (see Heitmueller, 2005; Kan, 2003)—this literature has not considered cross-border commuting as an alternative to migration though commuting plays an important role in border regions between European Union (and neighbouring non-EU) countries.

Likewise, although future and present consumption preferences can strongly influence decisions to move across borders, earlier papers (for example, those following Galor (1986) who focuses on aggregate welfare effects of time preference using overlapping generations models (see, e.g., Crettez, Michel, \& Vidal, 1996; 
Meier, 2000)) have not considered the possibility of cross-border commuting and the implications of time preference in border regions where both types of mobility are possible.

This article therefore extends the previous literature by analysing the effects of risk aversion and time preference on cross-border migration and commuting intentions both theoretically (Section 2) as well as empirically using a unique individual level dataset that documents mobility preferences in three CEE countries (Section 3). The empirical analysis, which is based on a multinomial probit model (Section 4), shows that the effect of time preference on the willingness to migrate or commute is nonlinear while risk aversion is found to have a negative effect on both commuting and migration propensities.

The article not only sheds light on the roles of individual risk aversion and time preference for mobility decisions but also highlights the importance of considering cross-border commuting as an alternative mode of international labour mobility. Because theories on international migration cannot merely be extended to cross-border commuting decisions, incorporating the possibility to commute across borders helps to achieve a better understanding of both the driving forces behind cross-border mobility and the functioning of labour markets in border regions.

\section{Theoretical model}

To analyse the effects of risk aversion and time preference on migration and cross-border commuting propensities, assume that there are two countries, home $(h)$ and foreign $(f)$, with nominal wage levels of $w_{s}^{h}$ and $w_{s}^{f}$ and price levels of $p_{s}^{h}$ and $p_{s}^{f}$, respectively, where $s$ is a time index. Let us also assume that in the initial period $t, w_{t}^{f}>w_{t}^{h}$ and $p_{t}^{f}>p_{t}^{h}$, but $\tilde{w}_{t}^{f}>\tilde{w}_{t}^{h}$, where $\tilde{w}=w_{s}^{i} / p_{s}^{i}$ is the real wage in country $i=\{h, f\}$ at time $s$. Finally, future income is discounted via a time-invariant discount rate of $\tau \in[0,1]$, representing $\tau=1 /(1+\rho)$, where $\rho$ is the rate of time preference (the preference for current consumption): a higher $\rho$ corresponds to a lower discount rate. Although differences in income tax rates between the home and foreign countries may also affect mobility decisions (Wołowiec and Soboń, 2011), they are not explicitly considered in the following analysis. Instead, the real and nominal wages are assumed to be net of taxes.

We assume that an individual currently living and working in $h$ can choose between living and working in $f$ ("migrating"), living in $h$ but working in $f$ ("cross-border commuting"), or continuing to live and work in $h$ ("staying"). We first consider the individual's choice to either migrate or remain in the home country before analysing the decision whether to commute across a border or work in the home country $h$. We then analyse the decision to either migrate or commute across a border if both modes of mobility are preferred to staying in the home country.

\subsection{Migrating vs. staying}

Following Sjaastad (1962), an individual living in country $h$ will be willing to migrate to country $f$ if the discounted gain from earning a higher income abroad during period $s \in[t, T]$ exceeds the costs of migration $M$ (which may also capture differences in amenities between $h$ and $f$; see Hunt and Mueller (2004), Okamoto (2007) and Krupka (2009) for examples):

$\sum_{s=t}^{T} \tilde{w}_{s}^{f} \tau^{s-t}-\sum_{s=t}^{T} \tilde{w}_{s}^{h} \tau^{s-t}>M$

When the choice to migrate is a one-time decision and the individual will not return to $h, T$ represents the period of retirement. Alternatively, one may consider an individual deciding where to work over the next $z$ years (so that $T=t+z$ ) to allow for the possibility of return migration. If the individual expects real wages in $h$ and $f$ to increase at annual rates of $\gamma^{h}$ and $\gamma^{f}$, Equation (1) can be rewritten as

$\sum_{s=t}^{T} \tilde{w}_{t}^{f}\left(1+\gamma^{f}\right)^{s-t} \tau^{s-t}-\sum_{s=t}^{T} \tilde{w}_{t}^{h}\left(1+\gamma^{h}\right)^{s-t} \tau^{s-t}>M$

$\tilde{w}_{t}^{f} \sum_{s=t}^{T}\left[\left(1+\gamma^{f}\right) \tau\right]^{s-t}-\tilde{w}_{t}^{h} \sum_{s=t}^{T}\left[\left(1+\gamma^{h}\right) \tau\right]^{s-t}>M$

which simplifies to

$\tilde{w}_{t}^{f} \frac{1-\left[\left(1+\gamma^{f}\right) \tau\right]^{T-t+1}}{1-\left(1+\gamma^{f}\right) \tau}-\tilde{w}_{t}^{h} \frac{1-\left[\left(1+\gamma^{h}\right) \tau\right]^{T-t+1}}{1-\left(1+\gamma^{h}\right) \tau}>M$

Whether the income gain exceeds the costs of migration depends on the level of real wages at time $t$, the wage growth rates both in the home country and abroad and the discount rate. It is also indirectly affected by age, which determines the length of the time span $T-t$.

However, the decision to migrate is also a decision under uncertainty. To incorporate the effect of un- 
certainty into the model, assume that the individual knows the initial real wage level in the home country $\tilde{w}_{t}^{h}$ and that the individual carries expectations of wage growth trends both in the home country $\gamma^{h}$ and abroad $\gamma^{f}$. However, the individual is not certain of the real wage level abroad (due to uncertainties surrounding the nominal wage or price levels). This simplified assumption is justifiable because the decision to migrate is ultimately determined by the income differential between working in one's home country and working abroad. Whether such uncertainty arises from uncertainty about wages abroad, uncertainty about wages in the home country, or both is ultimately irrelevant to the following discussion. It is, however, more natural to assume that the individual is better informed about home country wages than about wages abroad. When defining $\Pi(r)$ as a risk premium that increases in individual risk aversion $r$ $(\partial \Pi(r) / \partial r>0, \Pi(r)>0$ for risk-averse, $\Pi(r)=0$ for risk-neutral and $\Pi(r)<0$ for risk-loving individuals) so that $E\left[u\left(\tilde{w}_{t}^{f}\right)\right]=u\left(E\left[\tilde{w}_{t}^{f}\right]-\Pi(r)\right)$, expression (2) can be written as

$\left(\mathrm{E}\left[\tilde{w}_{t}^{f}\right]-\Pi(\mathrm{r})\right) \frac{1-\left[(1+\gamma)^{\mathrm{f}} \tau\right]^{\mathrm{T}-\mathrm{t}+1}}{1-\left(1+\gamma^{\mathrm{f}}\right) \tau}$

$-\tilde{w}_{t}^{h} \frac{1-\left[(1+\gamma)^{\mathrm{h}} \tau\right]^{\mathrm{T}-\mathrm{t}+1}}{1-\left(1+\gamma^{\mathrm{h}}\right) \tau}-\mathrm{M}>0$

The risk premium may also reflect alternative risks such as a less-than-one probability of finding employment abroad. If we write the discounted income differential of migration as

$\Delta_{M}=\left(E\left[\tilde{w}_{t}^{f}\right]-\Pi(r)\right) \frac{1-\left[\left(1+\gamma^{f}\right) \tau\right]^{T-t+1}}{1-\left(1+\gamma^{f}\right) \tau}$

$-\tilde{w}_{t}^{h} \frac{1-\left[\left(1+\gamma^{h}\right) \tau\right]^{T-t+1}}{1-\left(1+\gamma^{h}\right) \tau}$

and define an index function $I$

$I=\left\{\begin{array}{lll}1 & \text { if } & \Delta_{M}-M>0 \\ 0 & \text { if } & \Delta_{M}-M \leq 0\end{array}\right.$

the probability of being willing to migrate is given by $\operatorname{Pr}(I=1)$. All else being equal, this probability increases with the expected real wage abroad $E\left[\tilde{w}_{t}^{f}\right]$ and decreases with risk aversion $r$, home country real wage $\tilde{w}_{t}^{h}$ and migration cost $M$.
The influence of the discount rate $\tau$, however, depends on expectations of wage growth both in the home country and abroad. If $\gamma^{f} \geq \gamma^{h}$, the individual will expect wages abroad to grow at a faster (divergence scenario) or equivalent rate (equal growth scenario) compared with wages in the home country. An increase in the discount rate (a decrease in the time preference rate) will then increase the present discounted value of the expected real wage abroad by more than the present discounted value of the real wage in the home country. This, in turn, increases (all else being equal) the individual's willingness to migrate. In a divergence or equal growth scenario, the discount rate should therefore have an unambiguously positive effect on the willingness to migrate.

The solid line in Figure 1 shows the evolution of $\Delta_{M}$ for various levels of $\tau$ under an equal growth scenario, assuming $\gamma^{f}=\gamma^{h}=0.025$. As the discount rate approaches one (the rate of time preference approaches zero), the present discounted value of the income differential grows exponentially: the income differential is positive for each future period; as $\tau$ draws closer to one, more future differentials enter the individual's decision-making process. In a divergence situation, the exponential growth of $\Delta_{M}$ would be even more pronounced. In an equal growth or divergence scenario, $\tau$ thus has an unambiguously positive effect on the probability of being willing to migrate.

Conversely, if the individual expects $\gamma^{f}<\gamma^{h}$ so that wages in the home converge to (but not exceed) wages abroad over the time period $[t, T]$ (convergence scenario), the discounted income differential will also increase in $\tau$, but the effect will decline as the discount rate approaches one: as future income becomes less discounted, $\Delta_{M}$ increases as long as the real wage in the home country does not exceed the real wage abroad. However, because the income differential becomes smaller with every period, additions to the present discounted value also grow smaller as the discount rate increases. This trend is shown by the dashed line in Figure 1, which assumes that the real wage in the home country increases twice as fast as the real wage abroad $\left(\gamma^{h}=0.05, \gamma^{f}=0.025\right)$ : the increase in $\Delta_{M}$ declines as $\tau$ approaches one. If wage convergence results in an equalisation of real wages, an increase in the discount rate does not change the value of $\Delta_{M}$. In a convergence scenario, $\tau$ therefore has a positive but decreasing effect on the probability of being willing to migrate. 


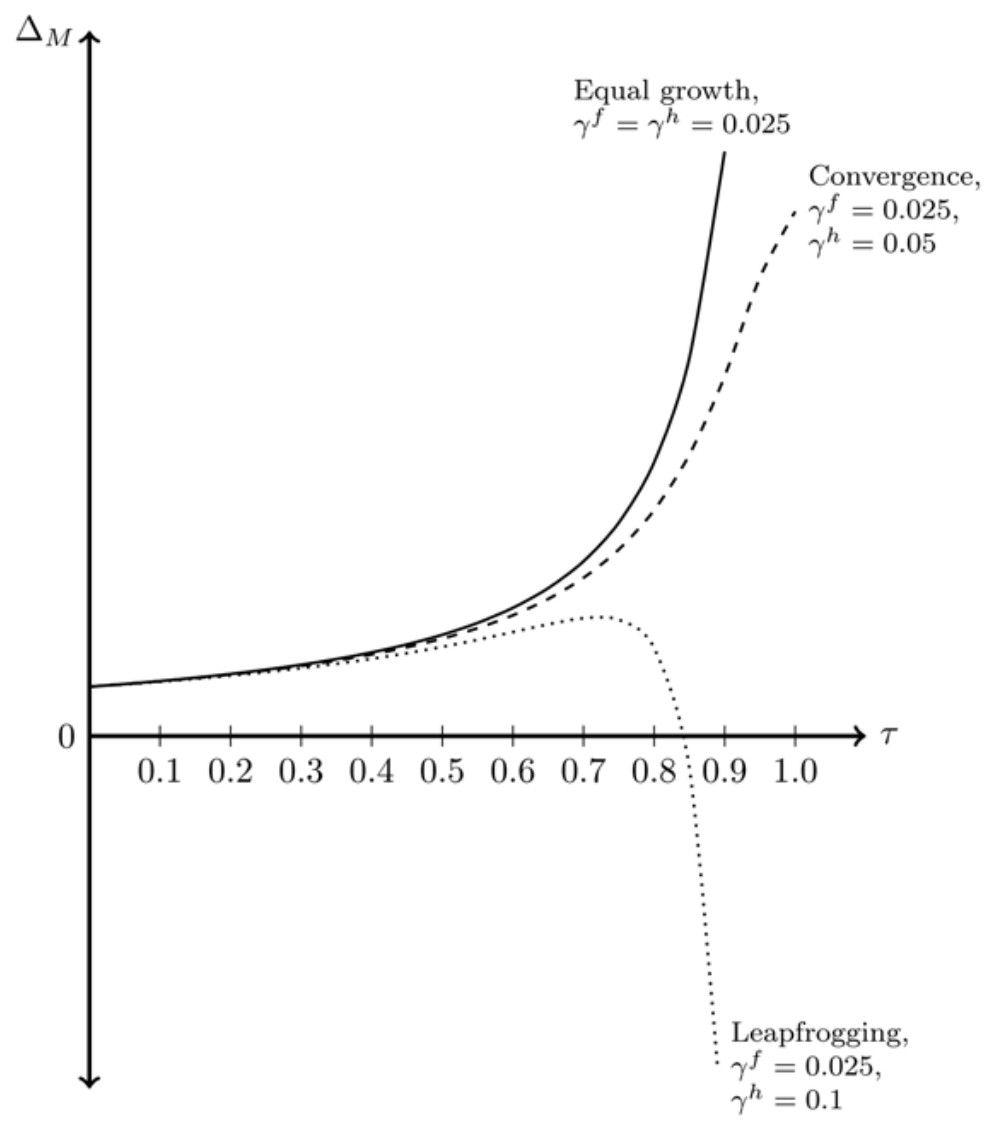

Figure 1. Discounted income differential $\Delta_{M}$ for various values of $\tau$ under equal growth, convergence and leapfrogging scenarios. Assumptions: $E\left[\tilde{w}_{t}^{f}\right]=2, \tilde{w}_{t}^{h}=1, \Pi(r)=0.3, T-t=30$.

Finally, if the individual expects $\gamma^{f} \ll \gamma^{h}$, the real wage in the home country will eventually surpass the real wage abroad during interval $[t, T]$ (leapfrogging scenario), and $\Delta_{M}$ may even become negative as $\tau$ increases. Beginning from a situation in which the individual is only concerned about current consumption ( $\tau=0$ ), an increase in the discount rate will initially increase the present discounted value of migration. The positive income differences that occur in the near future increase the present discounted value while negative differentials in the far future are still heavily discounted. However, as $\tau$ approaches a value of one, future losses become increasingly less discount- ed, and an increase in $\tau$ will eventually decrease the present discounted value of migration and $\operatorname{Pr}(I=1)$ as a result.

This scenario is shown by the dotted line in Figure 1 , which assumes that wage growth in the home country is four times larger than the growth rate of wages abroad $\left(\gamma^{h}=0.1, \gamma^{f}=0.025\right)$ : initially, an increase in $\tau$ also leads to an increase in $\Delta_{M}$. However, between $\tau=0.7$ and $\tau=0.75$, the marginal effect of the discount rate becomes negative; $\Delta_{M}$ declines and eventually becomes negative as it approaches a value of one. Therefore, in a leapfrogging scenario, the discount rate has a nonlinear effect on the probability of being will- 
ing to migrate because $\Delta_{M}$ is positive for low values of $\tau$ but may become negative as the discount rate approaches a value of one.

To summarise, the probability of being willing to migrate over staying in the home country ceteris paribus increases with expected wages abroad but decreases with home country wages, migration costs and risk aversion. Risk-averse individuals are thus less inclined to migrate abroad than risk-neutral or risk-loving individuals. Whether an increase in the discount rate (a decrease in the rate of time preference) increases or decreases the probability of being willing to migrate depends on expectations of future wage growth in the home country and abroad. Among individuals who expect home country wages to remain below wages abroad (convergence, equal growth and divergence scenarios), those with a discount rate closer to one should be more willing to migrate than those who discount future income heavily. However, among individuals who expect home country wages to surpass wages abroad in the future, individuals with a higher discount factor may be less willing to migrate.

Similar to the effect of $\tau$, the effect of age (which decreases the potential number of periods during which an individual may earn income abroad, $T-t$ ) on $\operatorname{Pr}(I=1)$ is also ambiguous and depends on $\gamma^{f}$ and $\gamma^{h}$ : if $\gamma^{f} \geq \gamma^{h}$, the propensity to migrate unequivocally decreases with age (increases with $T-t$ ) because age determines the number of years a higher wage may be earned abroad, which in turn raises the present discounted value of migration. Younger individuals should therefore be more willing to migrate, and the propensity to migrate should decrease with age. However, if $\gamma^{f}<\gamma^{h}$, the effect of age may become positive (the effect of $T-t$ may become negative) because as an individual spends a longer time period abroad, there is a higher likelihood that the home country real wage will eventually exceed the real wage abroad.

\subsection{Cross-border commuting vs. staying}

But migration is not the only possible option for cross-border labour mobility if individuals are able to instead commute across the border. There are a number of differences between migration and cross-border commuting. First, unlike migrants who work and consume abroad, cross-border commuters enjoy the option to consume in their home country where the price level can be assumed to be lower than abroad. The factor that influences the decision to commute across a border is thus not the real wage but the nominal wage abroad in relation to price level differences. Second, unlike migration costs that are paid up front, commuting costs accrue for each period and are thus affected by the discount rate. An individual will therefore be willing to commute across a border if

$\sum_{s=t}^{T} \frac{w_{s}^{f}}{p_{s}^{h}} \tau^{s-t}-\sum_{s=t}^{T} \tilde{w}_{s}^{h} \tau^{s-t}>\sum_{s=t}^{T} C \tau^{s-t}$

where $C$ is the per-period cost of commuting. If we define the relative price level as $P_{s}=p_{s}^{f} / p_{s}^{h}$, the above expression can be rewritten as

$\sum_{s=t}^{T} \tilde{w}_{s}^{f} P_{s} \tau^{s-t}-\sum_{s=t}^{T} \tilde{w}_{s}^{h} \tau^{s-t}>\sum_{s=t}^{T} C \tau^{s-t}$

Assuming, as before, that the expected rate of wage growth abroad and in the home country is $\gamma^{f}$ and $\gamma^{h}$, uncertainty will arise concerning the real wage level abroad $\tilde{w}_{t}^{f}$. Including the assumption that expected inflation is the same in the home country and abroad, the inequality simplifies to

$\sum_{s=t}^{T}\left(E\left[\tilde{w}_{t}^{f}\right]-\Pi(r)\right)\left(1+\gamma^{f}\right)^{s-t} P_{t} \tau^{s-t}$

$-\sum_{s=t}^{T} \tilde{w}_{t}^{h}\left(1+\gamma^{h}\right)^{s-t} \tau^{s-t}>\sum_{s=t}^{T} C \tau^{s-t}$

or

$\left(E\left[\tilde{w}_{t}^{f}\right]-\Pi(r)\right) P_{t} \frac{1-\left[\left(1+\gamma^{f}\right) \tau\right]^{T-t+1}}{1-\left(1+\gamma^{f}\right) \tau}$
$-\tilde{w}_{t}^{h} \frac{1-\left[\left(1+\gamma^{h}\right) \tau\right]^{T-t+1}}{1-\left(1+\gamma^{h}\right) \tau}>C \frac{1-\tau^{T-t+1}}{1-\tau}$

Denoting the left-hand side of inequality (5) as $\Delta_{C}$ and defining $J$ as an index function results in the following:

$J=\left\{\begin{array}{lll}1 & \text { if } & \Delta_{C}-C \frac{1-\tau^{T-t+1}}{1-\tau}>0 \\ 0 & \text { if } & \Delta_{C}-C \frac{1-\tau^{T-t+1}}{1-\tau} \leq 0\end{array}\right.$

$\operatorname{Pr}(J=1)$ is the probability of being willing to commute to $f$ vis-à-vis remaining in $h$. Similar to $\operatorname{Pr}(I=1), \operatorname{Pr}(J=1)$ increases with the expected real wage abroad $E\left[\tilde{w}_{t}^{f}\right]$ and decreases with risk aversion , the home country real wage $\tilde{w}_{t}^{h}$ and mobility cost $C$. Furthermore, it increases with the price level ratio 
$P_{t}$ because for given real wages in the home country and abroad and for a given price level abroad, a higher $P_{t}$ implies that home country prices are lower, which in turn increases the purchasing power of income earned abroad.

As outlined above, the effect of the discount rate depends on the expected levels of real wage growth for the home and foreign countries. In a divergence, equal growth or convergence scenario, the effect of the discount rate on the propensity to commute across borders is positive. In a leapfrogging scenario $\Delta_{C}$ initially increases with $\tau$ but later decreases as the discount rate approaches a value of one because a higher discount rate implies a higher present value of commuting costs. Therefore, a nonlinear effect of the discount rate on the probability of being willing to commute across a border can be expected.

The effect of age also depends on $\gamma^{f}$ and $\gamma^{h}$. In the equal growth and divergence scenarios, a higher $T-t$ should increase the willingness to commute, and the willingness to commute across a border should decrease with age (increase with $T-t$ ). But as is the case for migration, in convergence and leapfrogging scenarios the effect of age may become positive (the effect of $T-t$ may become negative) because a longer time period that an individual spends abroad corresponds with a higher chance that home country wages will eventually exceed wages abroad, especially for individuals with levels of $\tau$ close to one.

\subsection{Migrating vs. cross-border commuting}

Because the payoffs from commuting and migrating may both be positive, it is important to also consider the choice between these two modes of cross-border labour mobility. Let index function $K$ denote the individual's choice to migrate over cross-border commuting; the probability of preferring migration to commuting can be derived through a comparison between Equations (3) and (5). After minor reorganisation, this yields

$$
\begin{aligned}
& \operatorname{Pr}(K=1)=\operatorname{Pr}\left(\Delta_{M}-M>\Delta_{C}-C \frac{1-\tau^{T-t+1}}{1-\tau}\right)= \\
& \operatorname{Pr}\left(\left(E\left[\tilde{w}_{t}^{f}\right]-\Pi(r)\right)\left(1-P_{t}\right) \frac{1-\left[\left(1+\gamma^{f}\right) \tau\right]^{T-t+1}}{1-\left(1+\gamma^{f}\right) \tau}>\right. \\
& \left.M-C \frac{1-\tau^{T-t+1}}{1-\tau}\right)
\end{aligned}
$$

According to Equation (7), the probability that migration will be preferred to commuting depends on the relative price levels in the home country and abroad. If the price level in both countries is the same $\left(P_{t}=1\right)$, the left-hand side of the inequality is zero, and the decision between migrating and commuting depends only on the difference between the migration costs $M$ and the discounted commuting costs $C\left(1-\tau^{T-t+1}\right) /(1-\tau)$. If the price level abroad is higher than the price level in the home country $\left(P_{t}>1\right)$, the left-hand side of the inequality is negative. In this case, only those individuals with present discounted commuting costs that are considerably higher than migration cost (for example those who live far away from the border) will choose to migrate. All other individuals will prefer commuting over migrating to capitalise on the opportunity to consume at cheaper prices in their home countries. If, on the other hand, $P_{t}<1$ and the price level abroad is lower than the price level of the home country, individuals will favour migrating over commuting unless the migration costs are considerably higher than the present discounted commuting costs.

Following the initial assumption that $p_{t}^{f}>p_{t}^{h}$, a higher expected real wage abroad $E\left[\tilde{w}_{t}^{f}\right]$ will ceteris paribus be associated with a lower willingness to migrate than to commute. Given mobility costs and relative price levels, a higher expected real wage abroad will increase both the willingness to migrate and the willingness to commute. But because the price level of the home country is lower than the price level abroad, an increase in the expected real wage abroad will increase incentives to commute by a larger margin than incentives to migrate because an increase in the expected real wage abroad raises the individual's purchasing power in her home country. It also implies that a higher level of risk aversion $r$ is associated with a higher willingness to migrate than to commute. While a higher risk premium decreases both the willingness to migrate and the propensity to commute, the willingness to commute decreases by a larger margin because the associated decrease in purchasing power has a larger impact on commuting outcomes than it does on migration outcomes.

The effect of age and the discount rate on the choice between commuting and migrating is ambiguous. If $P_{t}=1$, the choice between migrating and commuting depends only on the relative costs of mobility, and an 
increase in the discount rate or $T-t$ will increase the present discounted value of commuting costs while the costs of migration remain unaffected. Both variables should therefore be associated with a higher willingness to migrate than to commute. The same holds true if $P_{t}<1$. If, however, $P_{t}>1$, an increase in the discount rate or of $T-t$ lowers both sides of Equation (7).

\subsection{Summary of predictions drawn from the theoretical model}

To summarise, several hypotheses can be tested empirically concerning the effects of risk aversion and time preference on the choice between migrating, commuting and staying in the home country. First, the discount rate (the rate of time preference) should have a positive (negative) effect on both the willingness to migrate and the willingness to commute. The effect may, however, be nonlinear if potentially mobile individuals expect wages in the home country to exceed wages abroad in the near future. In this case, lower discount rate levels should correspond with higher propensities towards both migrating and commuting, though the effect will become negative as $\tau$ approaches a value of one.

Second, for given wages and costs of mobility, higher levels of risk aversion should decrease propensities towards both migrating and commuting vis-à-vis staying in the home country. Potential migrants and crossborder commuters are thus less risk-averse than those who remain in their home countries. But a comparison between the two modes of mobility reveals that higher risk aversion levels should ceteris paribus also be associated with higher preferences for migration compared to commuting. Risk-averse individuals should therefore rather be willing to migrate than willing to commute. This depends, however, on the assumption that the price level in the home country is lower than the price level abroad. If individuals expect prices abroad to be the same as home-country prices, risk aversion should not affect preferences for migrating vs. commuting. If individuals expect prices abroad to be lower than home-country prices, higher levels of risk aversion should decrease the willingness to commute across a border less than the willingness to migrate.

These empirical hypotheses can be tested using a multinomial probit model in three dimensions derived from Equations (4), (6) and (7). In contrast to the more common multinomial logit model, the mul- tinomial probit model allows for an arbitrary covariance structure between response categories and does not require the restrictive "independence of irrelevant alternatives" assumption (see Maddala, 1983 or Train, 2009 for a recent discussion).

\section{Data and variables}

To analyse the effects of time preference and risk aversion on the willingness to migrate or to commute, the empirical analysis uses individual-level survey data collected between September and November 2010 that were acquired through personal face-to-face interviews within the scope of two projects entitled FAMO ("Fachkräftemonitoring", skilled labour monitoring) and AFLA ("Arbeitskräftemobilität und Fachkräftebedarf nach der Liberalisierung des österreichischen Arbeitsmarktes", labour mobility and demand for skilled labour after the opening of the Austrian labour market). The aim of these projects was to acquire information on the willingness to commute and to migrate in the Czech Republic, Slovakia and Hungary. In both projects, quota sampling was applied to ensure a representative sample of the working-age population of 15 years and older, with quotas defined by age, sex and educational attainment at a regional (NUTS 2) level. The empirical analysis, however, focuses only on individuals between 25 and 54 years of age; furthermore, students, retired workers and individuals who already work abroad are excluded from the sample because student and retiree mobility may be driven by other factors than work-related mobility. A total of 5,252 observations are available: 2,114 for the Czech Republic, 1,412 for Slovakia and 1,726 for Hungary.

The data are especially suitable for the empirical analysis in this paper. First, there are sufficient economic incentives for cross-border labour mobility due to large differences in wages and economic development between the countries considered and neighbouring countries such as Austria or Germany. Consequently, a substantial proportion of potentially mobile labour can be expected. Second, because the free mobility of workers from the studied countries to their immediate neighbours Germany and Austria was still restricted at the time of the interviews due to transitional arrangements in place until May 2011, mobility intentions (rather than realised mobility) still played an important role during the study period. Third, es- 
pecially in the border regions of the Czech Republic to Germany and Austria and the border regions of Slovakia and Hungary to Austria both types of mobility are possible. The region under consideration can thus be considered a model region for analysing the willingness to migrate and to commute across borders.

\subsection{Willingness to migrate and commute}

The dependent variable for the empirical analysis is the individual's willingness to migrate, commute or stay in her home country based on questions concerning cross-border mobility preferences. In the survey, the interviewees were asked, "Would it be conceivable for you to work abroad?", with the possible answers being "yes" or "no". Those who answered the question affirmatively were then asked whether they would prefer "daily commuting", "weekly commuting", "monthly commuting" or "living and working abroad". Those who stated a preference for daily and weekly commuting were categorised as "willing to commute" $(J=1)$, and those who preferred "living and working abroad" or "monthly commuting" were categorised as "willing to migrate" ( $I=1)$. All persons who did not express a willingness to migrate or to commute were labelled as "stayers" $(I, J=0)$. In contrast to the theoretical analysis, individual preferences that demonstrate a willingness to both migrate and commute $(I=1 \wedge J=1)$ cannot be derived from the data. Thus, in the empirical analysis $I=1$ if $K=1$ and $J=1$ if $K=0$.

On average, approximately $16.1 \%$ of the respondents reported a willingness to migrate, and $10.0 \%$ reported a willingness to commute (Table 1). The willingness to work abroad varied considerably across countries and was highest in Hungary, where $23.2 \%$ were willing to migrate and $14.9 \%$ were willing to commute; the lowest was observed in Slovakia, where $10.7 \%$ reported a willingness to migrate and only $4.5 \%$ reported a willingness to commute across a border. These variations in mobility intentions can be explained by differences in economic conditions between the three countries at the time of the survey. According to Eurostat figures, in 2010 the real growth rate of the Slovak GDP was $4.4 \%$ and the Czech GDP had grown by $2.5 \%$, while real GDP growth in Hungary was only $1.1 \%$. Furthermore, while the Czech Republic and Slovakia enjoyed a period of considerable growth between 2004 and 2008, with average real GDP growth rates of 5.5 and $7.3 \%$, Hungary experienced a period of limited growth (2004-2008 average: $2.7 \%$ ), especially in 2007 and 2008. The Hungarian economy was also more heavily affected by the recession of 2009 (real GDP -6.8\%, compared with $-4.9 \%$ in Slovakia and $-4.5 \%$ in the Czech Republic). In addition, the Hungarian sample included a higher percentage of respondents who were unemployed or out of the labour force at the time of the survey, and these variables can be expected to raise mobility intentions (Table 1).

Because the data only contain information on stated rather than revealed preferences, the calculated willingness to migrate and commute across a border will overestimate true future mobility because not all mobility intentions will be realised. Furthermore, it cannot be ruled out that certain respondents may have reported a willingness to work abroad simply because the survey questions reminded them of the possibility to work in another country. It is thus possible that the option to work abroad was not present in the individual's mind-set prior to the interview because it was, for instance, clouded by a "threshold of indifference" (see van Houtum and van der Velde, 2004; van der Velde and van Houtum, 2004; van der Velde, Janssen, \& Houtum, 2005). This effect may thus have added to the overestimation of future mobility based on data about migration and commuting intentions.

Nevertheless, as shown by researchers such as van Dalen and Henkens (2008), intentions are goodthough not perfect-predictors of future mobility. Furthermore, the analysis of cross-border commuting and migration intentions by Huber and Nowotny (2013) showed that the empirical determinants of the willingness to migrate and to commute across the border are in line with outcomes predicted in the previous literature. Studying the determinants of mobility intentions therefore helps reveal the determinants of "real" migration and cross-border commuting decisions, and it can be expected that the factors that determine the individual's willingness to work abroad also affect her decision to work abroad.

\subsection{Measures of risk aversion and time preference}

To test the hypotheses arising from the theoretical model, measures of individual risk aversion and time preference are required. In this paper, measures of risk aversion and time preference are derived from two 
Table 1. Summary statistics for dependent and explanatory variables.

\begin{tabular}{|c|c|c|c|c|c|c|c|}
\hline \multirow[b]{2}{*}{ Variable } & \multicolumn{4}{|c|}{ Full sample } & \multicolumn{3}{|c|}{ Means by country } \\
\hline & Mean & S.D. & Min. & Max. & $C Z$ & SK & $\mathrm{HU}$ \\
\hline Stayer & 0.739 & 0.439 & 0.000 & 1.000 & 0.763 & 0.848 & 0.619 \\
\hline Migrant & 0.161 & 0.368 & 0.000 & 1.000 & 0.140 & 0.107 & 0.232 \\
\hline Commuter & 0.100 & 0.300 & 0.000 & 1.000 & 0.097 & 0.045 & 0.149 \\
\hline$\tau$ & 0.959 & 0.074 & 0.360 & 1.000 & 0.966 & 0.963 & 0.949 \\
\hline r & 0.986 & 0.048 & 0.000 & 0.600 & 0.986 & 0.985 & 0.987 \\
\hline Age & 39.322 & 8.738 & 25.000 & 54.000 & 38.997 & 39.458 & 39.610 \\
\hline Single & 0.304 & 0.460 & 0.000 & 1.000 & 0.293 & 0.316 & 0.306 \\
\hline Kids & 0.440 & 0.496 & 0.000 & 1.000 & 0.493 & 0.347 & 0.452 \\
\hline Network & 0.520 & 0.500 & 0.000 & 1.000 & 0.410 & 0.564 & 0.621 \\
\hline Previous mobility & 0.095 & 0.294 & 0.000 & 1.000 & 0.083 & 0.124 & 0.087 \\
\hline Car owner & 0.783 & 0.412 & 0.000 & 1.000 & 0.884 & 0.811 & 0.637 \\
\hline Home owner & 0.686 & 0.464 & 0.000 & 1.000 & 0.628 & 0.715 & 0.734 \\
\hline Commuter & 0.327 & 0.469 & 0.000 & 1.000 & 0.369 & 0.376 & 0.236 \\
\hline Female & 0.502 & 0.500 & 0.000 & 1.000 & 0.491 & 0.511 & 0.509 \\
\hline Primary educ. & 0.113 & 0.317 & 0.000 & 1.000 & 0.086 & 0.047 & 0.200 \\
\hline Secondary educ. & 0.708 & 0.455 & 0.000 & 1.000 & 0.747 & 0.728 & 0.643 \\
\hline Tertiary educ. & 0.179 & 0.384 & 0.000 & 1.000 & 0.167 & 0.225 & 0.157 \\
\hline English & 0.195 & 0.396 & 0.000 & 1.000 & 0.227 & 0.244 & 0.116 \\
\hline German & 0.134 & 0.340 & 0.000 & 1.000 & 0.160 & 0.099 & 0.129 \\
\hline Other foreign lang. & 0.403 & 0.491 & 0.000 & 1.000 & 0.429 & 0.780 & 0.063 \\
\hline Private sector & 0.558 & 0.497 & 0.000 & 1.000 & 0.554 & 0.666 & 0.473 \\
\hline Public sector & 0.182 & 0.386 & 0.000 & 1.000 & 0.183 & 0.126 & 0.227 \\
\hline Self-employed & 0.109 & 0.311 & 0.000 & 1.000 & 0.130 & 0.118 & 0.075 \\
\hline Unemployed & 0.067 & 0.250 & 0.000 & 1.000 & 0.049 & 0.039 & 0.111 \\
\hline Out of labour force & 0.085 & 0.279 & 0.000 & 1.000 & 0.084 & 0.051 & 0.114 \\
\hline$\underline{\text { Deprivation }}^{\dagger}$ & 0.375 & 1.562 & -7.000 & 9.000 & 0.468 & 0.250 & 0.363 \\
\hline Observations & & & & & 2,114 & 1,412 & 1,726 \\
\hline
\end{tabular}

Note: Summary statistics for dependent and explanatory variables. S. D. = standard deviation. $N=5,252$ observations and ${ }^{\dagger} N=5,249$ observations. CZ = Czech Republic, SK = Slovakia, HU = Hungary.

survey questions in which respondents were confronted with the following hypothetical situations:

Question 1: Suppose you have won a monetary amount in a lottery. However, the lottery will not pay out the prize to you until exactly one year from now. How much are you willing to pay to receive the \{monetary amount immediately rather than one year from now?
Question 2: Suppose you are being offered a lottery ticket that either wins you \{a monetary amount in cash immediately or nothing at all. Both events are equally probable. What is the most that you are willing to pay for such a lottery ticket?

The stated monetary amount was $€ 10,000$ in Slovakia, CZK 250,000 in the Czech Republic and HUF 1,000,000 in Hungary. 

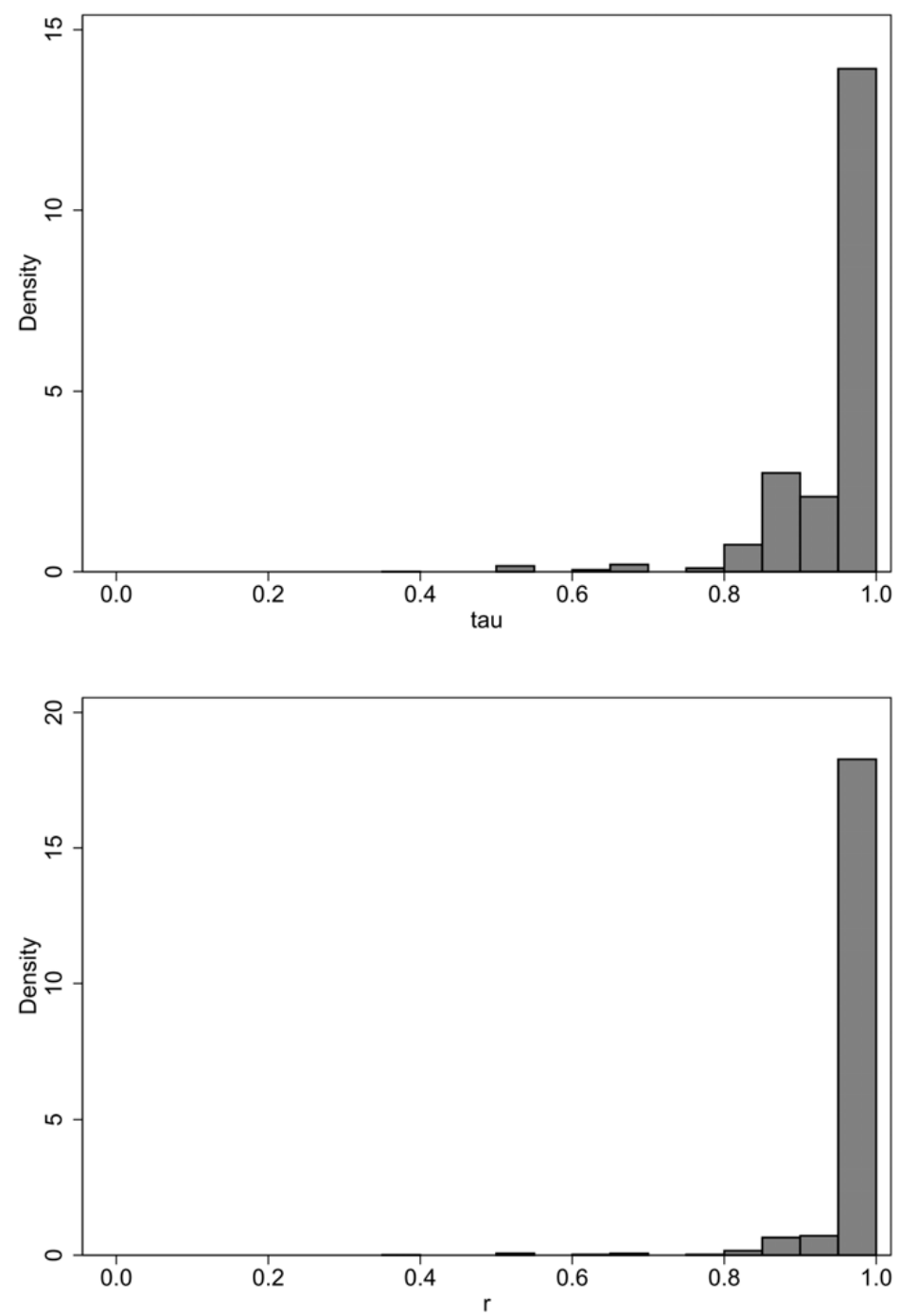

Figure 2. Empirical distributions of the discount factor $(\tau)$ and measure of risk aversion $(r) . N=5,252$ observations.

Denoting the total prize as $L$ (which was equal for both questions) and the response to the first question as $y$, the discount factor $\tau$ can be calculated as $\tau=1-y / L$. If, for example, the individual is willing to pay a sum of $€ 300$ to receive a prize of $€ 10,000$ today rather than one year from now, the discount fac- tor is $\tau=0.97$. On average, the respondents are willing to pay approximately $4.1 \%$ of the prize to receive it immediately rather than after a year. The average discount rate is thus $\tau=0.959$, but it varies considerably between 0.36 and 1 and is negatively skewed with a median of 0.990 . The top panel of Figure 2 shows the 
empirical distribution of the discount rate; summary statistics are provided in Table 1 .

The discount rate also varies among the examined countries. While the average discount rates in Slovakia $\left(\tau_{S K}=0.963\right.$ ) and the Czech Republic $\left(\tau_{C Z}=0.966\right)$ are rather similar, the mean discount rate is significantly lower in Hungary $\left(\tau_{H U}=0.949\right)$, which can be explained by the so-called "Magnitude Effect": small amounts are discounted to a greater degree than large amounts (see Frederick, Loewenstein, \& O'Donoghue, 2002) for an overview and a description of other discounted utility anomalies), and while the prizes listed for respondents in the Czech Republic and Slovakia were rather similar (using the average exchange rate during the period in which the interviews were conducted, CZK 250,000 amounted to approximately $€ 10,160$ ), the prize presented to the respondents in Hungary was of a lower value (about $€ 3,610$ ).

The measure for risk aversion was derived from the second question listed above. Denoting the answer to this question as $l$, risk-neutral individuals would be willing to pay the expected payoff to the lottery $l=L / 2$, while $l<L / 2$ would indicate a risk-averse individual and $l>L / 2$ would refer to a risk-loving individual. We can therefore define risk aversion as one minus the proportion of the lottery prize that the individual would be willing to pay for the lottery ticket $(r=1-l / L)$. If $r>0.5$, the individual is risk-averse; if $r=0.5$, she is risk-neutral; and if $r<0.5$, the individual is risk-loving. An increase in $r$ therefore indicates an increase in risk aversion. Because the mean willingness to pay for the lottery ticket was found to be $1.4 \%$ of the lottery prize, the measure of risk aversion is, on average, $r=0.986$. The distribution of $r$ is negatively skewed with a median of 0.999 . Only 18 of the 5,252 respondents were willing to pay the expected payoff of the lottery, and three were willing to pay more than 50 $\%$ of the lottery prize and can thus be identified as riskloving. In contrast to the discount rate measure, the measure for risk aversion does not vary significantly between the examined countries. The empirical distribution of $r$ is shown in the bottom panel of Figure 2 .

Before proceeding, it is important to highlight the assumptions that underlie the selection of discount rate and risk aversion measures, which may point to limitations in the approach. First, it is assumed that the discount factor $\tau$ and the measure of risk aversion $r$ remain constant over time. Although certain studies show that discount factors vary over the life cycle (e.g., Trostel and Taylor, 2001), it can be assumed that the discount factor and rate of risk aversion were perceived as being constant for the individual at the time of the interview. A number of studies, for example, use age as a proxy for the discount rate (e.g., Burda, 1993) and thus also implicitly assume a constant discount rate over the life cycle. The same holds true for risk aversion, which is also assumed to be time-invariant in studies on related topics (e. g., Kan, 2003).

Second, it may be argued that discount rates derived from hypothetical situations are not representative of the discount rates that occur in real situations and that real-life behaviour by individuals may contradict the behaviour they report when confronted with hypothetical situations. However, even if quantitative differences between individual discount rates computed from answers to hypothetical questions and real-life discount rates do exist, one can assume that the two will be correlated and that both methods will yield similar qualitative results with respect to interpersonal comparisons. Thus, the discount rate calculated here provides a good proxy for the real discount rate in cross-sectional regressions.

Third, though wealth may affect risk aversion, information on initial wealth is not available in the data. It must therefore be assumed that wealth plays only a minor role in determining risk aversion levels.

\subsection{Other explanatory variables}

The selection of other explanatory variables follows, among others, Huber and Nowotny (2013), who analysed cross-border commuting and migration intentions using similar data collected between 2004 and 2007. Age emerged as an important variable from the theoretical discussion because it decreases the value of $T-t$, which denotes the number of periods that an individual can work abroad. Age is therefore also considered an explanatory variable in the multinomial probit regression. As shown in Section 2, the probability of being willing to migrate vs. staying - and versus commuting-increases with the number of years that an individual can potentially work abroad under equal growth and divergence scenarios, but this effect can be negative depending on the expected real wage growth in the home and foreign countries. 
Mobility costs also play an important role in determining migration and commuting propensities. Because the direct costs of mobility are not observable for migration and commuting intentions, variables that are designed to capture indirect costs of commuting and migration, such as dummy variables for marital status ("Single") and the presence of children in the household ("Kids"), are included. Previous research suggests that persons living in larger households will face higher migration costs than single households (Mincer, 1978). Furthermore, variables that measure whether respondents have family members or friends working abroad are included to proxy for potential network effects ("Network") because networks have been shown to affect mobility decisions by reducing mobility (and job search) costs significantly (e.g., Bartel, 1989; McKenzie \& Rapoport, 2010; Pedersen, Pytlikova, \& Smith, 2008).

We also control for whether an individual has previously worked abroad ("Previous mobility") because prior migration experience can make searching for employment abroad more efficient, which in turn reduces search costs. Furthermore, dummy variables are included for car and home ownership ("Car owner" and "Home owner"): while the former can be assumed to decrease commuting costs, the latter will increase the opportunity costs of migration. As done by $\mathrm{Hu}-$ ber and Nowotny (2013), the empirical analysis also includes a dummy variable for individuals who are currently commuting to work in their home country ("Commuter") because commuting in the home country reduces the opportunity costs of moving abroad, which should increase both the willingness to migrate and to commute. Conversely, commuting may also suggest a strong preference for one's current region of residence, which would thus decrease the willingness to migrate. Finally, regional dummy variables at the NUTS 2-level are included to capture regional differences in the costs of migration and commuting such as distances from potential workplaces, accessibility and transport infrastructure characteristics.

Apart from these model variables, a dummy variable for women is included in the empirical model ("Female"). To control for skill levels and determinants of earnings possibilities abroad, dummies for educational attainment ("Primary education", "Secondary education" or "Tertiary education", with primary education as the base category) and dummies for knowledge of a foreign language ("English", "German" and "Other foreign language") are considered. Language skills affect the psychological costs of living and/or working abroad and can therefore also impact the total (pecuniary and non-pecuniary) mobility costs (the dummy variables assume a value of one only if the respondent reported having strong oral and written command of the language, and a value of zero was assigned for those who reported being able to speak only a few sentences of the language or who indicated a limited capacity to communicate in the language). Finally, the regression controls for the employment status of the respondents ("Private sector" employee, "Public sector" employee, "Self-employed", "Unemployed" and "Out of labour force", with those employed in the private sector as the base category) and the level of relative deprivation. Deprivation is measured as the difference between the respondents' assessments of their friends' and relatives' living conditions on an 11-point Likert scale and their own perceived living conditions ("Deprivation"). As shown by Huber and Nowotny (2013), relatively deprived individuals show a higher willingness both to migrate and to commute. Summary statistics for the independent variables can be found in Table 1 .

\section{Empirical analysis}

The results of the multinomial probit regression for the willingness to migrate, commute or stay are shown in Table 2. Model 1 includes only $\tau, r$ and age alongside the regional dummy variables. Model 2 also includes the variables used to proxy migration and commuting costs and the other explanatory variables discussed in Section 3.3 (the coefficients of the 18 regional dummy variables at the NUTS 2-level are not reported). Because the effect of $\tau$ may be nonlinear (see Section 2.1), the squared value of the variable is also included in the regression. The estimated marginal effects are shown in Table 3.

Beginning with the simplest regression that includes only the variables related to the theoretical model of Section 2 (Model 1), the discount rate was found to have a positive but diminishing effect on the willingness to migrate or commute, although the coefficient of $\tau$ was only significant at the $10 \%$ level. However, as shown by Ai and Norton (2003), in nonlinear models, the sign and significance of interaction terms cannot 
Table 2. Multinomial probit regression for the willingness to migrate, commute or stay in the home country.

\begin{tabular}{|c|c|c|c|c|c|c|}
\hline \multirow[b]{2}{*}{ Variables } & \multicolumn{3}{|c|}{ Model 1} & \multicolumn{3}{|c|}{ Model 2} \\
\hline & $\begin{array}{c}\text { Migrate } \\
\text { vs. } \\
\text { stay }\end{array}$ & $\begin{array}{c}\text { Commute } \\
\text { vs. } \\
\text { stay }\end{array}$ & $\begin{array}{l}\text { Migrate } \\
\text { vs. } \\
\text { commute }\end{array}$ & $\begin{array}{c}\text { Migrate } \\
\text { vs. } \\
\text { stay }\end{array}$ & $\begin{array}{c}\text { Commute } \\
\text { vs. } \\
\text { stay } \\
\end{array}$ & $\begin{array}{c}\text { Migrate } \\
\text { vs. } \\
\text { commute }\end{array}$ \\
\hline$\tau$ & $\begin{array}{l}7.024^{*} \\
(3.768)\end{array}$ & $\begin{array}{l}8.527^{*} \\
(4.752)\end{array}$ & $\begin{array}{l}-1.503 \\
(5.246)\end{array}$ & $\begin{array}{l}7.549^{*} \\
(4.044)\end{array}$ & $\begin{array}{l}6.689 \\
(5.025)\end{array}$ & $\begin{array}{l}0.860 \\
(5.441)\end{array}$ \\
\hline$\tau \wedge 2$ & $\begin{array}{l}-4.761^{* *} \\
(2.251)\end{array}$ & $\begin{array}{l}-5.556^{* *} \\
(2.793)\end{array}$ & $\begin{array}{l}0.795 \\
(3.093)\end{array}$ & $\begin{array}{l}-4.833^{* *} \\
(2.427)\end{array}$ & $\begin{array}{l}-4.204 \\
(2.964)\end{array}$ & $\begin{array}{l}-0.629 \\
(3.221)\end{array}$ \\
\hline r & $\begin{array}{l}-1.941^{* * *} \\
(0.620)\end{array}$ & $\begin{array}{l}-2.765^{* * *} \\
(0.649)\end{array}$ & $\begin{array}{l}0.824 \\
(0.698)\end{array}$ & $\begin{array}{l}-1.734^{* *} \\
(0.708)\end{array}$ & $\begin{array}{l}-2.755^{* * *} \\
(0.728)\end{array}$ & $\begin{array}{l}1.021 \\
(0.755)\end{array}$ \\
\hline Age & $\begin{array}{l}-0.042^{* * *} \\
(0.004)\end{array}$ & $\begin{array}{l}-0.016^{* * *} \\
(0.004)\end{array}$ & $\begin{array}{l}-0.026^{* * *} \\
(0.005)\end{array}$ & $\begin{array}{l}-0.023^{* * *} \\
(0.004)\end{array}$ & $\begin{array}{l}-0.011^{* *} \\
(0.005)\end{array}$ & $\begin{array}{l}-0.011^{* *} \\
(0.006)\end{array}$ \\
\hline Single & & & & $\begin{array}{l}0.426^{* * *} \\
(0.083)\end{array}$ & $\begin{array}{l}0.105 \\
(0.095)\end{array}$ & $\begin{array}{l}0.321^{* * *} \\
(0.105)\end{array}$ \\
\hline Kids & & & & $\begin{array}{l}-0.223^{* * *} \\
(0.081)\end{array}$ & $\begin{array}{l}-0.119 \\
(0.087)\end{array}$ & $\begin{array}{l}-0.104 \\
(0.099)\end{array}$ \\
\hline Network & & & & $\begin{array}{l}1.655^{* * *} \\
(0.080)\end{array}$ & $\begin{array}{l}1.624^{* * *} \\
(0.090)\end{array}$ & $\begin{array}{l}0.031 \\
(0.107)\end{array}$ \\
\hline Previous mobility & & & & $\begin{array}{l}0.461^{* * *} \\
(0.105)\end{array}$ & $\begin{array}{l}0.356^{* * *} \\
(0.118)\end{array}$ & $\begin{array}{l}0.105 \\
(0.125)\end{array}$ \\
\hline Car owner & & & & $\begin{array}{l}-0.036 \\
(0.090)\end{array}$ & $\begin{array}{l}0.202^{*} \\
(0.108)\end{array}$ & $\begin{array}{l}-0.238^{* *} \\
(0.118)\end{array}$ \\
\hline Home owner & & & & $\begin{array}{l}-0.150^{*} \\
(0.081)\end{array}$ & $\begin{array}{l}0.148 \\
(0.094)\end{array}$ & $\begin{array}{l}-0.298^{* * *} \\
(0.103)\end{array}$ \\
\hline Commuter & & & & $\begin{array}{l}-0.119 \\
(0.077)\end{array}$ & $\begin{array}{l}0.053 \\
(0.082)\end{array}$ & $\begin{array}{l}-0.173^{*} \\
(0.094)\end{array}$ \\
\hline Female & & & & $\begin{array}{l}-0.423^{* * *} \\
(0.071)\end{array}$ & $\begin{array}{l}-0.332^{* * *} \\
(0.078)\end{array}$ & $\begin{array}{l}-0.091 \\
(0.089)\end{array}$ \\
\hline Secondary educ. & & & & $\begin{array}{l}0.055 \\
(0.117)\end{array}$ & $\begin{array}{l}-0.063 \\
(0.127)\end{array}$ & $\begin{array}{l}0.119 \\
(0.144)\end{array}$ \\
\hline Tertiary educ. & & & & $\begin{array}{l}0.064 \\
(0.144)\end{array}$ & $\begin{array}{l}-0.258 \\
(0.163)\end{array}$ & $\begin{array}{l}0.322^{*} \\
(0.183)\end{array}$ \\
\hline English & & & & $\begin{array}{l}0.348^{* * *} \\
(0.094)\end{array}$ & $\begin{array}{l}-0.296^{* * *} \\
(0.115)\end{array}$ & $\begin{array}{l}0.644^{* * * *} \\
(0.124)\end{array}$ \\
\hline German & & & & $\begin{array}{l}0.442^{* * *} \\
(0.095)\end{array}$ & $\begin{array}{l}0.626^{* * *} \\
(0.101)\end{array}$ & $\begin{array}{l}-0.184^{*} \\
(0.111)\end{array}$ \\
\hline Other foreign lang. & & & & $\begin{array}{l}0.195^{* *} \\
(0.088)\end{array}$ & $\begin{array}{l}0.255^{* * *} \\
(0.098)\end{array}$ & $\begin{array}{l}-0.060 \\
(0.110)\end{array}$ \\
\hline Public sector & & & & $\begin{array}{l}-0.095 \\
(0.094)\end{array}$ & $\begin{array}{l}-0.279^{* * *} \\
(0.108)\end{array}$ & $\begin{array}{l}0.184 \\
(0.121)\end{array}$ \\
\hline Self-employed & & & & $\begin{array}{l}-0.418^{* * *} \\
(0.120)\end{array}$ & $\begin{array}{l}-0.195 \\
(0.124)\end{array}$ & $\begin{array}{l}-0.223 \\
(0.145)\end{array}$ \\
\hline Unemployed & & & & $\begin{array}{l}0.175 \\
(0.137)\end{array}$ & $\begin{array}{l}0.266^{*} \\
(0.153)\end{array}$ & $\begin{array}{l}-0.091 \\
(0.166)\end{array}$ \\
\hline Out of labour force & & & & $\begin{array}{l}-0.467^{* * *} \\
(0.135)\end{array}$ & $\begin{array}{l}-0.619^{* * *} \\
(0.157)\end{array}$ & $\begin{array}{l}0.151 \\
(0.178)\end{array}$ \\
\hline Deprivation & & & & $\begin{array}{l}0.057^{* * *} \\
(0.022)\end{array}$ & $\begin{array}{l}0.056^{* *} \\
(0.025)\end{array}$ & $\begin{array}{l}0.001 \\
(0.028)\end{array}$ \\
\hline Constant & $\begin{array}{l}0.026 \\
(1.697) \\
\end{array}$ & $\begin{array}{l}-2.126 \\
(2.128) \\
\end{array}$ & $\begin{array}{l}2.152 \\
(2.337) \\
\end{array}$ & $\begin{array}{l}-2.447 \\
(1.842) \\
\end{array}$ & $\begin{array}{l}-2.898 \\
(2.267) \\
\end{array}$ & $\begin{array}{l}0.452 \\
(2.439) \\
\end{array}$ \\
\hline Regional dummies & $\mathrm{Y}$ & $\mathrm{Y}$ & & & & \\
\hline $\begin{array}{l}\text { Observations } \\
\text { Log-likelihood }\end{array}$ & $\begin{array}{l}5,252 \\
-3,468.408\end{array}$ & $\begin{array}{l}, 249 \\
-2,881.008\end{array}$ & & & & \\
\hline
\end{tabular}

Note: Coefficients of regional dummy variables at the NUTS 2-level are not reported. Standard errors in parentheses. ${ }^{* * *}$ significant at $1 \%,{ }^{* *}$ significant at $5 \%,{ }^{*}$ significant at $10 \%$ level. 
Table 3. Average marginal effects from the multinomial probit regression for the willingness to migrate, commute or stay (Table 2)

\begin{tabular}{|c|c|c|c|c|c|c|}
\hline \multirow[b]{2}{*}{ Variables } & \multicolumn{3}{|c|}{ Model 1} & \multicolumn{3}{|c|}{ Model 2} \\
\hline & Stay & Migrate & Commute & Stay & Migrate & Commute \\
\hline \multirow[t]{2}{*}{$\tau$} & $0.460^{* * *}$ & $-0.270^{* * *}$ & $-0.190^{* *}$ & $0.273^{* *}$ & $-0.183^{*}$ & -0.091 \\
\hline & $(0.127)$ & $(0.102)$ & $(0.088)$ & $(0.114)$ & $(0.094)$ & $(0.084)$ \\
\hline \multirow[t]{2}{*}{ r } & $0.504^{* * *}$ & $-0.232^{* *}$ & $-0.272^{* * *}$ & $0.384^{* * *}$ & $-0.148^{*}$ & $-0.236^{* * *}$ \\
\hline & $(0.117)$ & $(0.094)$ & $(0.072)$ & $(0.109)$ & $(0.088)$ & $(0.070)$ \\
\hline \multirow[t]{2}{*}{ Age } & $0.007^{* * *}$ & $-0.006^{* * *}$ & -0.001 & $0.003^{* * *}$ & $-0.003^{* * *}$ & -0.000 \\
\hline & $(0.001)$ & $(0.001)$ & $(0.000)$ & $(0.001)$ & $(0.001)$ & $(0.001)$ \\
\hline \multirow[t]{2}{*}{ Single } & & & & $-0.052^{* * *}$ & $0.054^{* * *}$ & -0.002 \\
\hline & & & & $(0.013)$ & $(0.011)$ & $(0.010)$ \\
\hline \multirow[t]{2}{*}{ Kids } & & & & $0.032^{* * *}$ & $-0.026^{* *}$ & -0.005 \\
\hline & & & & $(0.012)$ & $(0.010)$ & $(0.009)$ \\
\hline \multirow[t]{2}{*}{ Network } & & & & $-0.292^{* * *}$ & $0.173^{* * *}$ & $0.119^{* * *}$ \\
\hline & & & & $(0.010)$ & $(0.010)$ & $(0.009)$ \\
\hline \multirow[t]{2}{*}{ Previous mobility } & & & & $-0.074^{* * *}$ & $0.051^{* * *}$ & $0.023^{* *}$ \\
\hline & & & & $(0.016)$ & $(0.013)$ & $(0.012)$ \\
\hline \multirow[t]{2}{*}{ Car owner } & & & & -0.011 & -0.011 & $0.023^{* *}$ \\
\hline & & & & $(0.014)$ & $(0.012)$ & $(0.011)$ \\
\hline \multirow[t]{2}{*}{ Home owner } & & & & 0.005 & $-0.025^{* *}$ & $0.020^{* *}$ \\
\hline & & & & $(0.012)$ & $(0.010)$ & $(0.009)$ \\
\hline \multirow[t]{2}{*}{ Commuter } & & & & 0.008 & $-0.018^{*}$ & 0.009 \\
\hline & & & & $(0.011)$ & $(0.010)$ & $(0.008)$ \\
\hline \multirow[t]{2}{*}{ Female } & & & & $0.069^{* * *}$ & $-0.047^{* * *}$ & $-0.022^{* * *}$ \\
\hline & & & & $(0.011)$ & $(0.009)$ & $(0.008)$ \\
\hline \multirow[t]{2}{*}{ Secondary educ. } & & & & -0.001 & 0.009 & -0.009 \\
\hline & & & & $(0.018)$ & $(0.015)$ & $(0.014)$ \\
\hline \multirow[t]{2}{*}{ Tertiary educ. } & & & & 0.012 & 0.017 & $-0.029^{*}$ \\
\hline & & & & $(0.022)$ & $(0.018)$ & $(0.016)$ \\
\hline \multirow[t]{2}{*}{ English } & & & & -0.014 & $0.057^{* * *}$ & $-0.042^{* * *}$ \\
\hline & & & & $(0.015)$ & $(0.012)$ & $(0.012)$ \\
\hline \multirow[t]{2}{*}{ German } & & & & $-0.092^{* * *}$ & $0.040^{* * *}$ & $0.052^{* * *}$ \\
\hline & & & & $(0.014)$ & $(0.012)$ & $(0.010)$ \\
\hline \multirow[t]{2}{*}{ Other foreign lang. } & & & & $-0.039 * * *$ & 0.018 & $0.021^{* *}$ \\
\hline & & & & $(0.013)$ & $(0.011)$ & $(0.010)$ \\
\hline \multirow[t]{2}{*}{ Public sector } & & & & $0.030^{* *}$ & -0.004 & $-0.026^{* *}$ \\
\hline & & & & $(0.014)$ & $(0.012)$ & $(0.010)$ \\
\hline \multirow[t]{2}{*}{ Self-employed } & & & & $0.056^{* * *}$ & $-0.047^{* * *}$ & -0.008 \\
\hline & & & & $(0.017)$ & $(0.014)$ & $(0.013)$ \\
\hline \multirow[t]{2}{*}{ Unemployed } & & & & $-0.041^{*}$ & 0.015 & 0.025 \\
\hline & & & & $(0.023)$ & $(0.019)$ & $(0.018)$ \\
\hline \multirow[t]{2}{*}{ Out of labour force } & & & & $0.089^{* * *}$ & $-0.043^{* * *}$ & $-0.045^{* * *}$ \\
\hline & & & & $(0.018)$ & $(0.015)$ & $(0.012)$ \\
\hline Deprivation & & & & $-0.010^{* * *}$ & $0.006^{* *}$ & 0.004 \\
\hline & & & & $(0.003)$ & $(0.003)$ & $(0.003)$ \\
\hline Regional dummies & Y & Y & & & & \\
\hline Observations & 5,252 & 5,249 & & & & \\
\hline
\end{tabular}

Note: Marginal effects of regional dummy variables at the NUTS 2-level are not reported. Standard errors in parentheses. *** significant at $1 \%$, ${ }^{* *}$ significant at $5 \%,{ }^{*}$ significant at $10 \%$ level. 

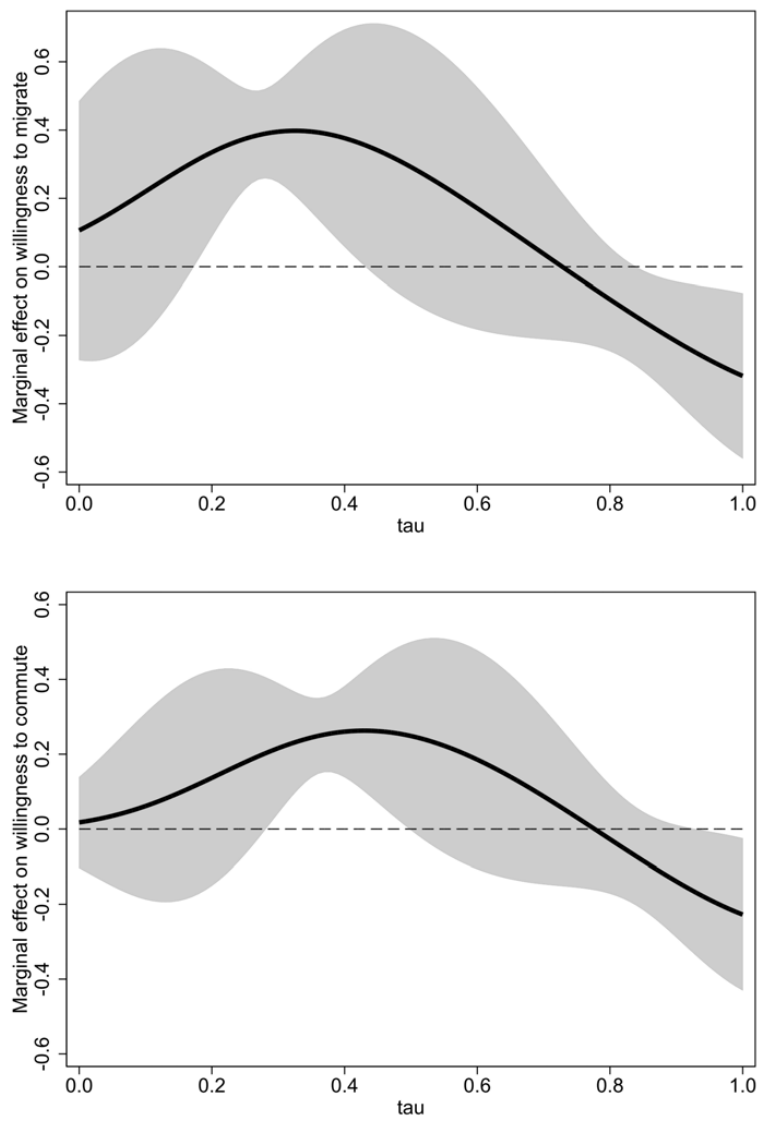

Figure 3. Average marginal effects of $\tau$ on the probability of being willing to migrate (top) and probability of being willing to commute (bottom) at various levels of $\tau$. Shaded area represents a $95 \%$ significance level. Calculated from Model 1 shown in Table 2.

be inferred from the coefficients or marginal effects alone. This rule also applies to squared terms, which are essentially interaction terms between a variable and itself. The average marginal effect of $\tau$ shown in Table 3 was therefore calculated taking the nonlinearity of the effect into account.

On average, the discount rate has a significantly negative marginal effect on both the willingness to migrate and the willingness to commute, while the average marginal effect on the probability of staying in the home country is positive. However, when the marginal effects are examined over the response sur- face, they are found to be positive for small values of $\tau$ but negative for values of $\tau$ that are closer to one. As shown in Figure 3, the average marginal effect of $\tau$ on the willingness to migrate is initially positive and increasing, although it is not significant for values of $\tau$ below 0.18 . The variable reaches a maximum value at approximately $\tau=0.33$ and then becomes negative at $\tau=0.73$. For values of $\tau$ that are close to a value of one, the marginal effect is significantly negative. While the picture for the effects on the willingness to commute is similar, the marginal effects are smaller in size and less often statistically significant. 

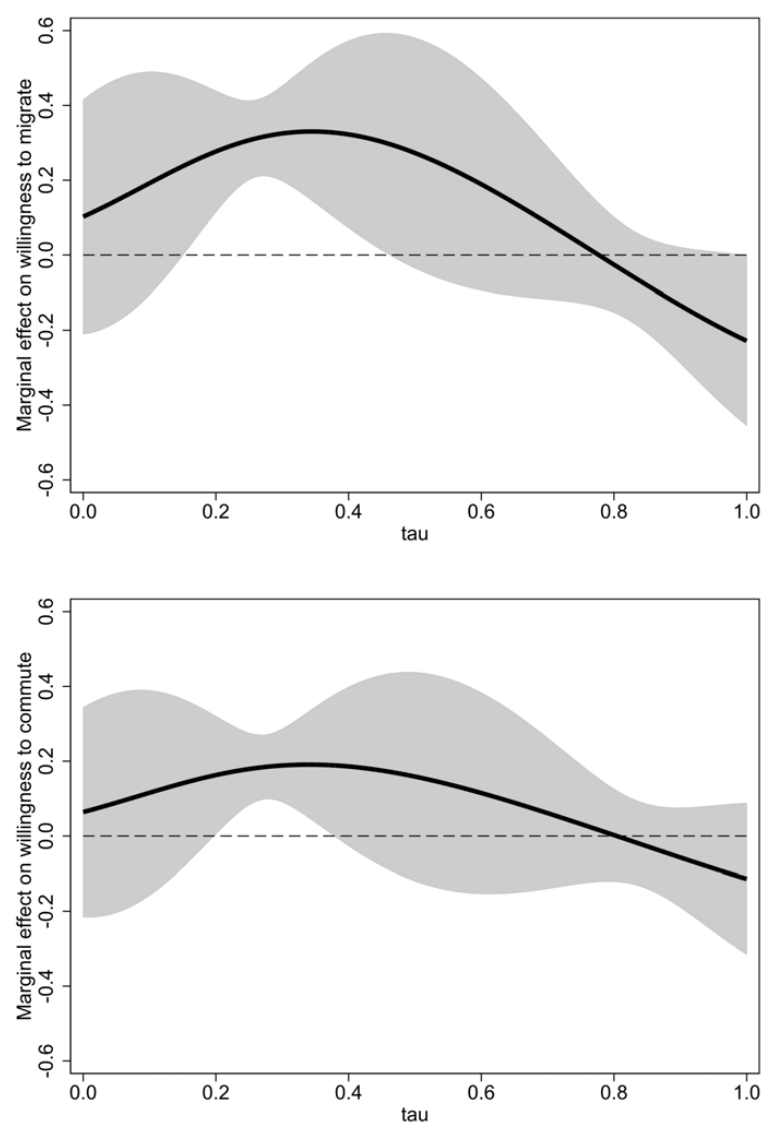

Figure 4. Average marginal effects of $\tau$ on probability of being willing to migrate (top) and probability of being willing to commute (bottom) at various levels of $\tau$. Shaded area represents a $95 \%$ significance level. Calculated from Model 2 shown in Table 2.

Following the discussion in Section 2, in which it was shown that the effect of the discount rate depends on expectations of future wage growth in the home country and abroad, these results suggest that most respondents expect a convergence or leapfrogging scenario, in which the home country real wages are expected to approach or even exceed real wages abroad. According to these scenarios, the discount rate would have a positive (marginal) effect in the beginning but would become negative as the discount rate approaches a value of one.
As expected, the effect of risk aversion is negative and highly significant for both mobility modes. Higher levels of risk aversion are thus associated with a lower propensity to migrate or commute. As hypothesised in Section 2.3, risk aversion has a positive effect on choosing migration instead of commuting when both modes of mobility are available. This effect is, however, not statistically significant.

Age has a negative effect on the willingness to migrate and the willingness to commute. Older individuals are thus less likely to move abroad. Accord- 
ing to Table 3, a one-year increase in age raises the probability of remaining in the home country by 0.7 percentage points. Age has a stronger effect on the willingness to migrate, and older workers are thus more willing to commute than migrate if they consider working abroad.

When all variables are entered into the regression (Model 2), the significance of the results for the discount rate declines: in the comparison between commuting and staying in the home country (Table 2), $\tau$ and $\tau$ squared are no longer significantly different from zero. The average marginal effect shown in Table 3 is also no longer significantly different from zero. This may be attributable to the fact that the discount rate is correlated with some of the other independent variables. Including these variables may thus decrease the precision of the estimate. Nevertheless, evaluated over the response surface, the marginal effect of the discount rate on the propensity to migrate or commute is still nonlinear, following a pattern that first rises and then falls with the value of $\tau$ (Figure 4). The effect of risk aversion is, however, still negative, and age again has a negative effect on both types of mobility.

The effects of the variables used to proxy for the costs of mobility are in line with expectations. Having children and being single both increase the probability of being willing to migrate. Neither variable affects the probability of being willing to commute. Possessing a network of friends or family who already live abroad has a considerable effect. Such networks increase the probability of being willing to migrate by an average of 17.3 percentage points while increasing the willingness to commute by 11.9 percentage points. Previous mobility experience also demonstrates the expected sign and increases both migration and commuting propensities. Owning a car increases the probability of being willing to commute while homeowners are less willing to migrate, as expected. The effect of being a commuter in the home country is, however, only significant at the $10 \%$ level for the willingness to migrate and enters the regression with a negative sign. This can be interpreted as demonstrating that the commuting variable measures individuals' preferences for their residence locations rather than mobility costs in the home country.

Among the other variables, we find a significantly lower willingness to migrate and commute among women, and individuals with secondary or tertiary education are neither more nor less willing to move abroad than those with only primary education (base category). Language knowledge does, however, have a significant effect. Knowledge of the English language increases the willingness to migrate and ceteris paribus decreases the willingness to commute. Conversely, German language knowledge and knowledge of a foreign language other than English or German increase both the willingness to migrate and to commute. This is attributable to the fact that daily or weekly commuting to the closest English-speaking countries are associated with considerable costs, while the Germanspeaking countries of Austria and Germany are within reasonable commuting and migration distance.

Turning finally to the dummy variables that capture employment status, we find that those working in the public sector are less willing to commute and that the self-employed are less willing to migrate. Being unemployed has a positive effect on the willingness to commute. This effect is, however, only significant at the $10 \%$ level. Strongly negative effects on both modes of mobility are observable among individuals who are currently out of the labour force. In part, this may be due to individuals on maternal/paternal leave, of whom lower mobility intentions can be expected in the short run, or due to discouraged workers who are less willing to seek employment, both in their home countries and abroad. Finally, complementing the results of Huber and Nowotny (2013), a higher level of relative deprivation is associated with an increased propensity to migrate or commute across a border.

\section{Conclusions}

This article analyses the effects of time preference and risk aversion on the willingness to become internationally mobile by considering both migration and cross-border commuting as modes of mobility. The theoretical model shows that starting from a situation in which the individual cares only about present consumption, a lower rate of time preference (a higher discount rate) will initially increase incentives to migrate or commute across a border. However, as the rate of time preference approaches a value of zero (the discount rate approaches one), the effect increasingly depends on expectations of real wage growth in the home country and abroad. If the individual expects wages in her home country to eventually exceed wages abroad 
("leapfrogging scenario"), an increase in the discount rate may even decrease the individual's willingness to become internationally mobile.

A higher level of risk aversion, however, decreases both the willingness to migrate and the propensity to commute across a border. The theoretical model also shows that the effect of age on migration and crossborder commuting propensities is ambiguous. On the one hand, age limits the maximum potential number of periods an individual can work abroad, which suggests that younger individuals should demonstrate a higher willingness to migrate or commute. On the other hand, if individuals expect home-country wages to exceed wages abroad in the future, age may have a positive effect on the willingness to work abroad.

Using a unique dataset on mobility intentions in the Czech Republic, Slovakia and Hungary, the empirical analysis based on a multinomial probit regression shows that the marginal effect of the discount rate on the willingness to migrate or commute is nonlinear and first increases, then decreases as the discount rate approaches a value of one. The empirical findings are consistent with a "convergence" or "leapfrogging" interpretation, in which individuals expect wages in their home countries to converge to and eventually exceed wages abroad in the future. The multinomial probit also reveals that a higher rate of risk aversion decreases the propensity to both migrate and commute, as expected. It also shows that age has a negative effect on both types of mobility but that this negative effect is stronger for the probability of being willing to migrate.

The regressions also highlight other significant differences between potential migrants and cross-border commuters. First, individuals who are currently not in a partnership are more willing to migrate but not necessarily more likely to commute. Second, home and car owners are significantly less likely to choose migration over commuting. Third, knowledge of the English language has a positive effect on the propensity to migrate but a negative effect on the propensity to commute.

The analysis thus sheds light on the roles of individual time preference and risk aversion in shaping cross-border commuting and migration decisions, which is especially important for integrating border regions. The study also shows that theories of international migration cannot simply be transferred to cross-border commuting because the two forms of mobility are driven by different factors. Additionally, common determinants affect the decisions to migrate or to commute across the border in different intensities. Explicitly considering the possibility of cross-border commuting via theoretical and empirical models therefore deepens our understanding of the drivers behind cross-border labour mobility and of the functioning of labour markets in border regions. More research on the determinants of migration and cross-border commuting and of the interdependencies between the two types of mobility is therefore needed. Future extensions of the present analysis may, for example, consider the possibility of return migration (or commuting abroad for a limited period of time) or include the endogenous determination of the timing of migration in a cross-border migration and commuting model.

\section{References}

Ai, C., \& Norton, E. C. (2003). Interaction terms in logit and probit models. Economics Letters, 80 (1), 123-129.

Anam, M., Chiang, S. H., \& Hua, L. (2008). Uncertainty and international migration: an option cum portfolio model. Journal of Labor Research, 29 (3), 236-250.

Bartel, A. P. (1989). Where do the new U. S. immigrants live?. Journal of Labor Economics, 7 (4), 371-391.

Burda, M. C. (1993). The determinants of East-West German migration: some first results. European Economic Review, 37 (2), 452-461.

Burda, M. C. (1995). Migration and the option value of waiting. Economic and Social Review, 27 (1), 1-19.

Crettez, B., Michel, P. \& Vidal, J. P. (1996). Time preference and labour migration in an OLG model with land and capital. Journal of Population Economics, 9 (4), 387-403.

Dixit, A. K. (1992). Investment and hysteresis. Journal of Economic Perspectives, 6 (1), 107-132.

Dixit, A. K., \& Pindyck, R. S. (1994). Investment under Uncertainty. Princeton, NJ: Princeton University Press.

Frederick, S., Loewenstein, G. \& O’Donoghue, T. (2002). Time discounting and time preference: a critical review. Journal of Economic Literature, 40 (2), 351-401.

Galor, O. (1986). Time preference and international labor migration. Journal of Economic Theory, 38 (1), 1-20. 
Heitmueller, A. (2005). Unemployment benefits, risk aversion, and migration incentives. Journal of Population Economics, 18 (1), 93-112.

Huber, P., \& Nowotny, K. (2013). Moving across borders: who is willing to migrate or to commute?. Regional Studies, 47 (9), 1462-1481.

Hunt, G. L., \& Mueller, R. E. (2004). North American migration: returns to skill, border effects, and mobility costs. The Review of Economics and Statistics, 86 (4), 988-1007.

Kan, K. (2003). Residential mobility and job changes under uncertainty. Journal of Urban Economics, 54 (3), 566-586.

Krupka, D. J. (2009). Location-specific human capital, location choice and amenity demand. Journal of Regional Science, 49 (5), 833-854.

Locher, L. (2001). Testing for the option value of migration (Discussion Paper No. 405). Institute for the Study of Labour.

Maddala, G. S. (1983). Limited Dependent and Qualitative Variables in Econometrics. New York, NY: Cambridge University Press.

McKenzie, D., \& Rapoport, H. (2010). Self-selection patterns in Mexico-U. S. migration: The role of migration networks. The Review of Economics and Statistics, 92 (4), 811-821.

Meier, V. (2000). Time preference, international migration, and social security. Journal of Population Economics, 13 (1), 127-146.

Mincer, J. (1978). Family migration decisions. Journal of Political Economy, 86 (5), 749-773.

O'Connell, P. G. J. (1997). Migration under uncertainty: 'Try your luck' or 'Wait and see. Journal of Regional Science, 37 (2), 331-347.

Okamoto, R. (2007). Location choice of firms and workers in an urban model with heterogeneities in skills and preferences. Regional Science and Urban Economics, 37 (6), 670-687.

Pedersen, P. J., Pytlikova, M., \& Smith, N. (2008). Selection and network effects-Migration flows into OECD countries 1990-2000. European Economic Review, 52 (7), 1160-1186.

Pindyck, R. S. (1991). Irreversibility, uncertainty and investment. Journal of Economic Literature, 29 (3), 1110-1148.

Sjaastad, L. A. (1962). The costs and returns of human migration. Journal of Political Economy, 70 (5), 80-93.
Train, K. E. (2009). Discrete Choice Methods with Simulation (2nd ed.).New York, NY: Cambridge University Press.

Trostel, P. A., \& Taylor, G. A. (2001). A theory of time preference. Economic Inquiry, 39 (3), 379-395.

van Dalen, H. P., \& Henkens, K. (2008). Emigration intentions: mere words or true plans? Explaining international migration intentions and behaviour (Discussion Paper No. 2008-60). Center for Economic Research. Tilburg University.

van der Velde, M., Janssen, M., \& van Houtum, H. (2005). Job Mobility in the Dutch-German Regional Labour Market: The Threshold of Indifference. In G. van Vilsteren \& E. Wever (Eds.), Borders and Economic Behaviour in Europe. A Geographical Approach (pp. 77-95). Assen: Royal Van Gorcum.

van der Velde, M., \& van Houtum, H. (2004). The threshold of indifference: rethinking immobility in explaining cross-border labour mobility. Review of Regional Research, 24 (1), 39-49.

van Houtum, H., \& van der Velde, M. (2004). The power of cross-border labour market immobility. Tijdschrift voor Economische en Sociale Geografie [Journal of Economic \& Social Geography], 95 (1), 100-107.

Wang, T., \& Wirjanto, T. S. (2004). The role of risk and risk aversion in an individual's migration decision. Stochastic Models, 20 (2), 129-147.

Wołowiec, T., \& Soboń, J. (2011). EU integration and harmonisation of personal income taxation. Contemporary Economics, 5 (1), 36-46.

\section{Acknowledgements}

Financial support by the Jubiläumsfonds der Oesterreichischen Nationalbank (project no. 13804) is gratefully acknowledged. Part of this research was written while the author was visiting researcher at the Regional Economics Applications Laboratory at the University of Illinois at Urbana-Champaign. The author would like to thank Peter Huber, René Böheim, participants of the European Congress of the Regional Science Association International and anonymous referees for helpful discus sion and stimulating comments on an earlier version of this paper. 
